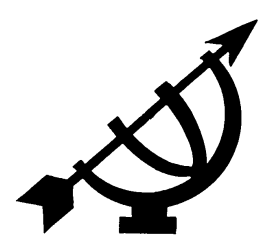

\title{
"Eat it again for the first time": Identity in a world of change
}

\author{
D.F.M. Strauss \\ Fakulteit Geesteswetenskappe \\ Universiteit van die Vrystaat \\ BLOEMFONTEIN \\ E-mail:dfms@cknet.co.za
}

\begin{abstract}
"Eat it again for the first time": Identity in a world of change

Our everyday experience is well acquainted with the reality of constancy (identity) and change. Persistence over time - continuity is normally accompanied by an awareness of change - discontinuity. Although the temptation is immediately to enter into logicalmathematical problems, this article wants to highlight first of all the underlying ontological issues and distinctions required to gain a better understanding of the familiar term "identity". In order to achieve this goal the idea of identity is related to the nature of an entity and its properties. Plato's account of identity and change paved the way for an enduring philosophical wrestling with this problem. A static logic of identity may rule out change (Von Kibèd), but on the basis of Galileo and Einstein the original insight of Plato, namely that change can only be established on the basis of constancy, acquires a new natural scientific meaning. Acknowledging the more-than-functional and multifunctional nature of the identity of an entity helps to avoid any attempt that wants to explain the nature of entities exhaustively in terms of one aspect only. It also supports the distinction between conceptual knowledge and concept-transcending knowledge. In the final analysis the human awareness of the identity of entities amidst change explores the foundational interconnectedness between the kinematic and the physical aspects in the context of concept-transcending knowledge.
\end{abstract}

\section{Opsomming}

"Eet dit opnuut vir die eerste keer": identiteit in 'n wêreld van verandering

Ons alledaagse lewenservaring is bekend met die realiteit van konstansie (identiteit) en verandering. Voortbestaan deur die loop van die tyd - kontinuïteit - is normaalweg vergesel deur 'n besef van ver- 
andering - diskontinuïteit. Alhoewel die versoeking bestaan om onmiddellik aandag te skenk aan logiese wiskundige probleme, wil hierdie artikel eers die onderliggende ontologiese kwessies belig deur aandag te gee aan die onderskeidings wat nodig is om 'n beter insig in die aard van die bekende term "identiteit" te gee. Met die oog op hierdie doel word die idée van identiteit in verband gebring met die aard van 'n entiteit en die eienskappe daarvan. Die weergawe wat Plato van identiteit en verandering gegee het, het die weg gebaan vir 'n voortgaande wysgerige worsteling met hierdie problem. 'n Statiese logika van identiteit mag verandering ter syde stel (Von Kibèd), maar gebaseer op die denke van Galileo en Einstein het Plato se insig, naamlik dat verandering slegs vasgestel kan word op die basis van konstansie, 'n nuwe natuurwetenskaplike betekenis aan konstansie verbind. Die erkenning van die meer-as-funksionele en multifunksionele aard van die identiteit van 'n entiteit help om te voorkom dat die aard van entiteite bloot in terme van een aspek verduidelik word. Dit ondersteun ook die onderskeiding tussen begripskennis en begripstransenderende kennis. In die laatste instansie ontgin die mens se besef van die identiteit van entiteite te midde van verandering die funderende samehang tussen die kinematiese en die fisiese aspekte in die konteks van begripstransenderende kennis.

\section{First orientation}

The well-known slogan from Kellogg's captured in the title is remarkable in two respects: firstly it highlights the apparently dialectical tension present in the human experience of alteration and continuation, dynamics and persistence; and secondly it captures something about ubiquity and contingency, as well as universality and individuality.

Although the phrase "eat it again" also incorporates an awareness of succession and continuity, the tail-end of the original phrase jumps to something new, discontinuous to whatever has been experienced before, "for the first time." A first interpretation may suggest that literally speaking we are indeed every time eating the same thing, namely Kellogg's, and that every time we eat the same thing (identity, continuity) it tastes as good as new, as if we are eating it for the first time (non-identity, discontinuity).

It seems therefore as if the advertisement introduces a gap or even stronger, a dialectical tension, between its first part and the second part. What is granted in the first part, namely that we are successively eating the same thing, is denied in the second part. This affirms that what we eat is something we have not eaten before, i.e., we are eating it for the first time. 
Affirmation and denial are well-known within the domain of logic. They relate to statements (propositions) and to the applicability of the two most basic principles governing logical reasoning, namely the principle of identity (principium identitatis) and the principle of non-contradiction (principium contradictionis). Quine explains:

The peculiarity of statements which sets them apart from other linguistic forms is that they admit of truth and falsity, and may hence be significantly affirmed and denied. To deny a statement is to affirm another statement, known as the negation or contradictory of the first (Quine, 1958b:1).

Yet, when it comes to the issue of identity, language does not resolve the issue, partially because lingual units are not mere copies of what is given within reality. Quine says: "The utility of language lies partly in its very failure to copy reality in any one-thing-onename fashion. The notion of identity is then needed to take up the slack" (Quine, 1958b:208). However, he does qualify this statement by pointing out that what are identical are the real extra-linguistic entities: "... and not the names with one another; the names stand in the statement of identity, but it is the named objects that are identified" (Quine, 1958b:208).

This view is defended, because Quine earlier already insisted that it is incorrect to assert that the laws of logic hold purely by virtue of language and to say that they are therefore analytic in character. 1

Quine did realise that the attempt to define analyticity 2 in terms of meaning runs into a circularity, since meaning is defined in terms of analyticity - causing Fodor to underscore that there is no meaningindependent way of characterising either analyticity or meaning (Fodor, 1977:43).

Once language as horizon is introduced, one may claim that human beings do not have an extra-lingual access to (identical) entities. Is

1 "Carnap maintained, and Frege before him, that the laws of logic held by virtue purely of language: by virtue of the meanings of the logical words. In a word, they are analytic. I have protested more than once that no empirical meaning has been given to the notion of meaning, nor, consequently, to this linguistic theory of logic" (Quine, 1973:78). On the next page, however, he does open the door for analyticity, but within a perspective that hinges on "social uniformity" "a sentence is analytic if everybody learns that it is true by learning its words" (Quine, 1973:79).

2 A sentence is supposed to be analytically true if it is true only on the basis of its meaning. 
this not intended by Derrida when he states: "There is nothing outside of the text [there is no outside-text; il n'y a pas de hors-text]" (Derrida, 1976:158)?

\section{Identity, entity and property}

Suppose we look at Frege's well-known example of the "evening star" and the "morning star." Frege used this example in order to distinguish between "Sinn" and "Bedeutung" (connotation and denotation). Although there are two different lingual signs involved, their reference (denotation) is the same. Van Woudenberg proposes to speak about an identity relation in cases similar to the "evening star" and the "morning star," and about the relation between entity and property when assertions like "the hat is white" are at stake (Van Woudenberg, 2000:12).

Hart makes the situation slightly more complex when he opens his work on our understanding of the world with the following explanation - an explanation focusing on the things we can experience, the properties (attributes) we can discern and the relations existing between these entities:

Our universe, the empirical world of time and space, is populated by little girls, white-tailed deer, yellow slippers, planets and many other things. We can attribute what may be called qualities, or functions, or properties to all of these entities in our world and we can say that they relate to each other. Little girls are cute and have mothers. White-tailed deer are fast and eat leaves. Yellow lady slippers have brown spots on their petals and need light. Planets move around the sun. We can record countless situations that always have these three elements: things with attributes in relation. Little girls feeling warm as they are cuddled by their mothers. White-tailed deer standing motionless as they listen to a sound. Yellow lady slippers hanging low as they bend under the weight of unexpectedly late snow (Hart, 1984:1).

These remarks are all dependent on the implicit assumption that entities endure over time. The Dutch language expresses this phenomenon by referring to "het zich zijn en zich blijven" of entities. 3 However, already early Greek philosophy challenged this assumption when Heraclitus argued that everything is taken up in

Transliterated: "the being and on-going existence of something". 
constant flux (Diels \& Kranz, 1959/1960: B Fr. 90).4 It was Cratylus, a younger contemporary of Socrates and associate teacher of Plato, who caused the latter to come to the one-sided view of the ideas found in the thought of Heraclitus. Cratylus interpreted Heraclitus to say that all perceptible things are in a process of change and that they are therefore unknowable. In his dialogue with the name Cratylus, Plato portrays Cratylus as claiming that since we cannot say "what is not" we are also unable to say what is false. Cratylus took change in such a radical sense that he even questioned references to what is the "same" - such as found in the alleged statement of Heraclitus that one cannot step into the same river twice: one cannot step into the same river even once (see Freeman, 1949:285). Apparently the implication of this radicalised position regarding change is that since there is never something to hold on to, identity is impossible as well.

\section{Plato on identity and change}

Behind this consequence we find the school of Parmenides denying multiplicity in its fundamental identification of thought and being. 5 Thought can only think what is, because it cannot contemplate what does not exist. Veling remarks that Parmenides inspired later thinkers to engage in a rational search for "true reality" amidst all that is changeful (Veling, 2000:29).

With an appeal to the logical principle of identity, Von Kibèd argues as follows against the (logical) "impossibility" of change. The continued existence of an entity over time is derived from an appeal to the (logical) law of identity:

The principle of identity, according to which everything is only identical to itself, actually forbids every change, every becomingdifferent, every stepping-outside of a substance from its beingitself (Von Kibèd, 1979:59).

Von Kibèd is well aware of the fact the some thinkers (like Aristotle) employ the distinction between essence and appearance to account both for the identity and the change of an entity:

4 In connection with the nature of thermodynamically open systems, we shall return to this Heraclitean idea of flux below.

5 Zeno's arguments against multiplicity and movement (Achilles and the Tortoise, the flying arrow, and so on), simply explore the basic position taken by Parmenides in his claim that thought and being are the same. 
The difficulties accompanying the concept of the changes of an unchangeable thing are side-stepped by dividing the entity into an essential and accidental part, thus producing the possibility to associate unchangeability with its essence and changeability with what is accidental (Von Kibèd, 1979:60).

However, according to Von Kibèd, this won't help us, because also the accidental features of an entity are subject to the law of identity: "according to the principle of identity also the accidental must remain identical to itself and cannot abolish its essence, which is given in its accidental nature" (Von Kibèd, 1979:60). His conclusion is therefore to be expected: "The concept of change is therefore logically unthinkable" (Von Kibèd, 1979:60). What is needed in order to account for change, namely "the concept of causality, is logically seen non-transparent and shows the limits of logical explanation" (Von Kibèd, 1979:60-61). In order to transcend this apparent impasse, we have to go back to Plato who found himself confronted with a thought climate, assuming that change belongs to the world of the senses. This caused Plato to struggle with distinctions untilised in his attempt to account for the possibility of knowledge. Plato realised that knowledge depend upon something more basic than change. From Heraclitus he had learned that all things accessible to sensory perception are in an ever-fluctuating state. It is therefore impossible to know these things. However, this conclusion rests on the presupposition that the existence of everything is exhausted by its state of change. Yet, if this is true, knowledge will be cancelled. The moment a claim of knowledge is made, it is uprooted because what is assumed to be known, will change the next moment. It will become something not yet known, in fact, it will change into something unknowable!

In order to secure the possibility of knowledge, Plato then postulated the enduring essential being of things (their static eidos) - which is supposed not to be subject to change (Plato, 1963: Cratylus, 439c440a). Without an awareness of endurance (persistence) the very notion of change becomes problematic, for the difficult question then is: "what" changes? For example, an ageing person can only claim to be ageing because there is a constant referrence to the same person! One can detect changes only on the basis of constancy this is the valuable insight of Plato's theory of ideas. While we may distance ourselves from the speculative (metaphysical) construction of transcendent ideal forms (static essences), we all still have to account for the brilliant insight that change rests on constancy. 


\section{Galileo and Einstein}

Since the development of Galileo's mechanics, classical physics attempted to understand all bodies in terms of the denominator of mechanical movement. The law of inertia assumes the constancy of motion if no physical forces interact with this movement. From Newton up to the beginning of the 20th century, this mechanistic tendency characterised the main development of modern physics. Max Plank characterised this mechanistic orientation as follows in 1910:

The conception of nature that rendered the most significant service to physics up till the present is undoubtedly the mechanical. If we consider that this standpoint proceeds from the assumption that all qualitative differences are ultimately explicable by motions, then we may well define the mechanistic conception as the conviction that all physical processes could be reduced completely to the motions (italics - DFMS) of unchangeable, similar mass-points or mass-elements (Planck, 1973:53).

In kinematics all processes are reversible in principle. This reversibility concerns the kinematical time order of uniformity (constancy). 6 As such it lies at the foundation of the dynamic changes discernable within physical processes of energy transformation. Already in 1824 Carnot discovered fundamentally irreversible physical processes. During the 19th century the implication of this discovery was further explored by Clausius and Thompson in their formulation of the second main law of thermodynamics. In 1865 Clausius introduced the term entropy. This law accounts for the irreversibility of physical processes, since it determines the direction of a physical (or chemical) process in a closed system.

Thus, the law of non-decreasing entropy was established as the second main law of thermodynamics. At the same time, the classical mechanistic reduction to pure motion was uprooted. Justifiably, therefore, Max Planck (in his mentioned article from 1910) remarks that the "irreversibility of natural processes" confronted the "mechanistic conception of nature" with "insurmountable problems"

6 This reversibility is analogous to numerical succession and spatial co-existence - which are both also reversible. The reversibility of the numerical time order first of all flows from the reversibility of the + and - directions in the system of integers. Although concrete events in physical reality are unidirectional, the time order within the numerical aspect could be experienced both in the positive and the negative directions. 
(Planck, 1973:55). The effect was that physicists had to acknowledge that physical time is irreversible. This irreversibility is manifested in the a-symmetrical relation of causality, for it stands to reason that the cause precedes the effect. Kant already realised that causality is not identical to succession, because although day and night (and: night and day) are succeeding each other, it is incorrect to say that either one is the cause of the other one.

In a different context Janich draws a clear distinction between phoronomic and dynamic statements. ${ }^{7}$ He states that the scope of the strict distinction between phoronomic (subsequently called kinematic) and dynamic arguments could be explained in terms of an example. Modern physics has to employ a dynamic interpretation of the statement that a body can alter its speed continuously only. Given certain conditions, a body can never accelerate in a discontinuous way, that is to say, it cannot change its speed through an infinitely large acceleration, because that will require an infinite force. 8

Since the discovery of radio-activity it turned out that within microstructures themselves there are irreversible processes present proceeding spontaneously in one direction only. In addition, this state of affairs, straightaway, confirms the irreducibility of the physical aspect to the kinematical aspect (with its reversible time order). It is therefore incorrect to say that "change" is the only "constant."

7 The early 19th century German philosopher, Von Baader, already employed a distinction between the mechanical and dynamical (see Von Baader, 1851:52 ff. - an exposition forming part of a contribution to a dynamic philosophy as opposed to a mechanical one: "Beiträge zur dynamischen Philosophie im Gegensatze zu der mechanischen").

8 "Die Tragweite einer strengen Unterscheidung phoronomischer (im folgenden kinematisch genannt) und dynamischer Argumente möchte ich an einem Beispiel erläutern, das ... aus der Protophysik stammt. Die Aussage 'ein Körper kann seine Geschwindigkeit nur stetig ändern' kann von der modernen Physik nur dynamisch verstanden werden. Geschwindigkeitsänderungen sind Beschleunigung, d.h. als Zweite Ableitung des Weges nach der Zeit definiert. Zeit wird von der Physik als ein Parameter behandelt, an dessen Erzeugung durch eine Parametermaschine ('Uhr') de facto bestimmte Homogenitätserwartungen geknüpft sind ... Bezogen auf dem Gang einer angeblich so ausgewählten Parametermaschine kann ein Körper seine Geschwindigkeit deshalb nich unstetig, d.h. mit unendlich große Beschleunigung ändern, weil dazu eine unendlich große Kraft erförderlich wäre" (Janich, 1975:68-69). 
Already in his Isagogè Philosophiae (1930) the Dutch philosopher, Vollenhoven, distinguished between the mechanical and the physical aspects. However, in the edition of 1936 this distinction no longer appears. His colleaugue, Dooyeweerd, on the contrary, initially maintained the order numerical, spatial, physical - thus identifying the kinematical aspect with the physical aspect. Round about 1950 he realised that this distinction is necessary to account for the fact that kinematics (phoronomy) can define an uniform motion without any reference to a causing force (compare Galileo's law of inertia). 9 That physical laws pre-suppose the meaning of the kinematic aspect, could be demonstrated with reference to the first main law of thermodynamics, currently known as the law of the conservation of energy. Already in 1847, at the youthful age of 26 , Helmholtz presented a formulation of this first main law of physics to the Physics Society of Berlin. He began by pointing out that nobody had succeeded in building a successful perpetual motion machine. This was a logical consequence of the indestructibility of energy. Up to this day physicists recognise this law as the law of energy conservation, which means that energy cannot be created or destroyed. What is at stake here is the constancy of energy. But the nature of constancy is precisely what Einstein employed in his special theory of relativity. One can indeed say that the crux of Einstein's theory of relativity is to be found in the nature of the (kinematic) order of constancy, which it presupposes. 10

Bryon and Spielberg correctly emphasise that Einstein's theory concerns "invariance" - i.e. constancy - but unfortunately they confused it with the terms absolute and unchanging:

Indeed, Einstein originally developed his theory in order to find those things that are invariant (absolute and unchanging) rather than the relative. He was concerned with things that are universal and the same from all points of view (Bryon \& Spielberg, 1987:6).

The term unchanging is simply the denial (negation) of change - a physical term. ${ }^{11}$ The physical aspect must not only be distinguished

9 See Dooyeweerd (1997-II:99). In Strauss (2003a) an account of the ontic status of the various modal aspects of reality is found, with special reference to the numerical and spatial aspects.

10 Both Einstein and Planck criticised the mechanistic main tendency of classical (Newtonian) physics (see Einstein, 1959:42 and Planck, 1973:65).

11 The term absolute cannot really be applied to anything in creation, that is, not if one wants to avoid the idolisation/absolutisation of created reality. 
from its foundational kinematic aspect, since there is also an indissoluble coherence between these two aspects. For this reason one shall find within the physical aspect a structural moment which reminds of the foundational meaning of the kinematic aspect. Constancy appears in the physical aspect as a structural reminder of the meaning of motion. In philosophical terms one may say that one finds an analogy of the kinematic aspect at the law side of the physical aspect (see Strauss, 2000).

A formulation of the first main law of thermodynamics, which intends to be true to reality, would therefore have to refer to energy constancy. Strictly speaking, the use of the term conservation is inadequate, since the activity of retention itself requires an input of energy - as in the case of thermodynamic "open systems" (or "steady states"). The law of energy constancy illustrates not only the distinct uniqueness of the kinematic and physical aspects, but, while taking into account the distinction between law side and factual side, also the indissoluble coherence between them: without the foundational position of the kinematic aspect in the order of the various cosmic aspects, we would have no grounds for discerning an analogy of the aspect of movement within the physical aspect, that is, the analogy of energy constancy. The distinctness and mutual coherence of constancy and change renders the statement that change is the only constant meaningless.

\section{Modes of explanation making identity understand- able}

The idea of an entity transcends any particular mode of explanation through which knowledge of entities is obtainable. One can explore different modes of explanation to demonstrate this perspective. But whenever any specific mode of explanation is used, two things ought to be kept in mind. Firstly, approaching an entity from one functional (aspectual) perspective only can never exhaust the full, many-sided existence of such an entity. Secondly, terms from any specific mode (aspect/function/facet) of reality could be used in a way stretching beyond the limits of the mode under consideration in which case it could be used in a concept-transcending way to refer to the entire existence of an entity.

When one speaks about the unity of an entity, the fact that it is one, a straight-forward appeal is made to the quantitative function of such an entity (in which case the numerical terms one and unity are used conceptually, i.e. they are employed to refer to the way in which an entity functions within the arithmetical aspect). The philosophical 
legacy of the West also explored the numerical intuition, by using it to refer to more than the mere quantitative aspect of an entity. The acknowledgement of the individuality and uniqueness of an entity is quantitatively conditioned in that it is distinct. This awareness of the individuality of an entity (its being distinct) does not merely capture the numerical qualities of an entity, since it at once alludes to all other features of it as well. In other words, functional terms, such as those having their seat within the quantitative mode of reality, can be used to refer to the way in which an entity functions within the boundaries of a specific aspect (the conceptual use of the terms one and unity), or the numerical intuition can be stretched in concepttranscending ways to refer to the total existence of an entity in terms of the idea of its uniqueness or individuality.

Therefore, when an entity is seen as an individual entity, i.e., as being distinct from other entities, the (co-conditioning) role of the quantitative mode is at stake. Yet this fact does not justify the elevation of number to become the "principle of individuation", as it is found in Aristotle, who connected the category of quantity with matter: "But all things that are many in number have matter" (Aristotle, 2001: Metaph., 1074a:33-34).

In addition to the just mentioned numerical mode of explanation, the description of an entity may explore the spatial mode, by adding a different specification, for instance when an entity is designated as an individual whole (totality). It is only when one explores the points of entry offered by the kinematical and physical aspects of reality, that one is capable of articulating a well founded intuition of identity. Then one can add further specifications in saying that an entity is an enduring individual whole, in spite of any changes to which it may be subjected. The term identity acquires a concept-transcending meaning in the sense that it stretches the original kinematical meaning of movement beyond its modal (aspectual) limits, to refer to the entity in the totality of its persistence (enduring existence). This idea of identity presupposes the core kinematical meaning of a uniform motion, but it cannot be reduced to it.

In general one can say that terms residing within a particular modal aspect may therefore be applied in a twofold sense: either as referring to phenomena functioning within the aspect concerned, or terms like these may be employed in such a way that they stand in the service of an understanding transcending the limited context of a specific mode of explanation. When the awareness of uniform motion is applied to the description of an uniformly moving body in a purely (abstract) kinematic sense, one may say that such a term is 
used in a conceptual way. However, the moment one expands the scope and uses the term constancy in order to refer to the identity of an entity over time in spite of changes it may experience, then the intuition of constancy is expanded in a concept-transcending way that is manifest in speaking about the identity of such an entity.

The phrase concept-transcending knowledge can be designated as idea-knowledge, where it is assumed that a form of thought is needed in order to capture that kind of knowledge transcending the limits of concept formation. 12 In general therefore our talking about the identity of things rests upon the basis of a concept-transcending idea of the transmodal reality of entities. ${ }^{13}$ It entails that entities belong to a distinct dimension of reality intimately cohering with another dimension of reality, namely that of modal functions (aspects). We only have access to entities because these aspects not only serve as modes of being and modes of explanation, but also as experiential points of entry to entities.

Lowe is justified in distinguishing between identity and unity: "A principle of individuation, we might say, is not so much a criterion of identity as a principle of unity" (Lowe, 1998:33). Instead of exploring the kinematical meaning of uniform motion and its expansion to the idea of the identity of an entity, Lowe reverts to the logicalmathematical criterion of identity advanced by Frege (see Lowe, 1998:41). ${ }^{14}$ Our basic concern is with the ontic identity of entities ${ }^{15}$

12 Nicolai Hartmann therefore aptly explained Kant's notion of the ideas of reason in a similar fashion. The thought-form required to think of an unknowable "thingin-itself" ("Ding an sich") is what a "Grenzbegriff" intends to capture (see Strauss, 2003b:254, particularly also note 17 about the translational equivalent of Grenzbegriff as concept-transcending knowledge). It should be noted that conceptual knowledge is constituted by universality, whereas idea-knowledge approximates what is unique, individual and contingent.

13 Dooyeweerd writes: "The transcendental Idea of the individual whole precedes the theoretical analysis of its modal functions. It is its pre-suposition, its cosmological a-priori" (Dooyeweerd, 1997-III:65).

14 Frege actually contemplates the context of logical and symbolical objectification - see Frege 1987:94 ff. (original text 62 ff.). Van Ingwagen also does not explore the twofold use of modal terms in combination with the basic ontic reality of endurance over time (see Van Ingwagen, 2001:95 ff.). Authors from the tradition of analytic philosophy tend to revert to logic as a basic orientation for considering the issue of identity without realising that the ontic conditions for identity precedes the meaning of logical analysis. This issue requires the special attention of a different article. 
- mindful of the Quinian slogan mentioned by Schulte: "No entity without identity" (Schulte, 1987:149).

One is now in a position to understand why Von Kibèd got stuck in a static logic of identity. It is because he disregarded the kinematic and physical points of entry to entitary reality. In other words, he did not acknowledge the uniqueness and coherence between constancy and dynamics.16 A fruitful ontology requires an articulated awareness of the multiple modal aspects of reality - such as it is found in the philosophical legacy of Dooyeweerd and Vollenhoven. ${ }^{17}$

\section{Mechanistic biology and the identity of living entities}

The immense successes of organic chemistry and biochemistry in unravelling the intricate physico-chemical functioning of living entities tempt modern biologists, who are inclined to a physicalistic approach, to over-accentuate the dynamic flow of the physicalchemical constituents of living entities. Just consider the fact that all the atoms of our body, even of our bones, are exchanged at least once every seven years; all the atoms in our face are renewed every six months; all our red blood cells every four months; and $98 \%$ of the protein in the brain in less than a month. Add to this that our white blood cells are replaced every ten days and one-thirteenth of all our tissue proteins are renewed every 24 hours, 18 then one may justifiably ask the question: what guarantees the identity of a living entity if all the candidates are caught up in a constant flux?

From a purely mechanistic or physicalistic point of view, a living thing is explicable in physical terms only. Then it must display a physico-chemical identity constituted by its atoms, molecules and

15 Frege certainly employs an appropriate expression when he speaks about "Identitätsurteile"/“identity propositions" (Frege, 2001:15). While he immediately relates such propositions to the logical principle of identity, our argument opts to account for the given ontic reality of enduring entities.

16 Once more one has to point out that Einstein did not develop a theory of relativity, but rather a theory of constancy.

17 Carnap proceeds from a fairly simplistic and reduced view when he discusses five basic relations as categories: "identity, similarity, intensity, time, and space" (Carnap, 1967:135). With these terms Carnap intends the numerical (identity), the spatial (similarity, space), the kinematical (time) and the physical (intensity). 
macro-molecules. The problem, however, is that all these constituents are constantly changing! Which of these physico-chemical components could then constitute this supposedly purely physicochemical identity of living things? Will it be those atoms, molecules, and macro-molecules currently present within it, those present years ago, or those that will be present a few years hence?

When living things are physicalistically reduced to their material constituents, their biotical identity is necessarily lost - since the supposed elements of identity continually vary. ${ }^{19}$

Yet, once the unique biotical function of living things is taken into account, it is even possible to claim that a living thing, considered in terms of the biotic mode of explanation, is in a stable state (referred to as health), while at the same time the claim can be made without any contradiction - that, considered in terms of a physicochemical mode of explanation (with a view to the flowing equilibrium of its physical-chemical constituents), it exists in an unstable state. 20 If the physical-chemical substratum of living things approaches a state of higher statistical probability, biotical instability increases as a sign of the final process of dying. ${ }^{21}$

From the preceding considerations, important consequences follow:

- Whenever an idea of identity is formulated, the decisive clue is always given in the mode of explanation involved. For example, compared to the physical identity of material entities, living entities display a biotical identity.

- Furthermore, whenever identity is the theme, at least an implicit awareness of the foundational relationship between constancy and dynamics is entailed.

19 Plato discusses the example of a wooden ship of which all the constitutive parts are replaced on sea (Plato, 1963: Phaido, 58; see the discussion of Van Woudenberg, 2000:28).

20 We should remember that Von Bertalanffy (on the basis of his idea of the dynamic equilibrium - Fliessgleichgewicht) generalised the second main law of thermodynamics to open systems (see Strauss, 2002b).

21 Heraclitus must have understood something of open systems with his idea of flux, because his thought exhibits an awareness of the reciprocity between persistence and change (see Diels \& Kranz, 1959/1960: B Fr.90). 
- Finally, since an entity is more than the sum of its different modes of explanation, no single (entitary) identity-claim can exhaust the uniqueness of any entity.

Sometimes a distinction is made between living and non-living entities: the first category applies to entities that retain their identity in spite of changes, whereas the second category refers to material things. Van Woudenberg remarks that the latter groups of entities can only be maintained through external intervention. It is clear that he did not realise that what Von Bertalanffy designated as a flowing equilibrium (Fliessgleichgewicht) - exemplified in a fire or glacier does not require external maintenance (such as in the case of Plato's ship). Consequently, there ought to be no objection to speak about the identity of physical entities as well. Endurance over a period of time may rather be questioned in terms of the "principle of the inderscernability of identicals" of Leibniz. This entailes that only when we restrict ourselves to a specific moment in time it is possible to affirm the identity of entities. However, as Van Woundenberg (2000:43) remarks, the idea of temporal parts does not side-step the awareness of identity over time, but presupposes it.22

\section{The problem of the mind-brain identity}

In spite of the fascinating detail brought to light by contemporary cognitive science, it must be clear that within this field one can easily end up with different modes of explanation, incorrectly appreciated as conflicting modes of explanation. An inclination towards the supposedly decisive biotical structure of the brain (as an organ) might have lost sight of other equally important modes of explanation. This is explored in approaches primarily interested in sensitive phenomena, in empirical detail about logical reasoning, about techno-formative skills (for instance in tool-making), in the uniquely human linguistic abilities, and so on.

If the distinction between modal function and (transmodal) entity is neglected, the fallacy of reification becomes actual. The concrete many-sidedness of human subjectivity and human agency transcends any mode of explanation because, as we have pointed out above, no single aspect exhaust human functioning. Therefore, if the brain is explained in terms of a mode different from the biotical, then the supposed mind-brain identity claim would be highly problematic (and recognised as reductionistic). Even the materialist 
(physicalist) claim that the brain is just a complex configuration of atoms, molecules and macromolecules, do not side-step the "modeof-explanation-transcending" entitary dimension of reality. The enduring identity of physically qualified entities is just as much a mystery (from the perspective of one functional explanation) as is the case with biotical or sensitively characterised entities. Any attempt to reduce the sensitive or biotic dimensions to the physical therefore does not give one a decisive (conceptual) understanding of the "what-ness" of material entities. For that reason Stegmüller is certainly justified, when he states that even for the science of the 20th century, the concept of matter is one of the most difficult and most mysterious concepts whatsoever. 23

Glas also proceeds from the idea of modal functions as modes of explanation, when he remarks that he employs the term level with reference to "the qualitative distinctiveness between modes of reality" and to the distinctiveness of modes and entities: "When the modal analysis of an aspect of reality is fundamental in the process of abstraction, then the entitary reformulation of this modal (or functional) point of view may become a first step into the direction of reification and undue substantializing" (Glas, 2002:154). In response to the approaches of Churchland and other neuroscientists, he highlights the shortcomings both of dualist and monist accounts:

Psychophysical dualism and dualist interactionism may be seen as a result of the unjustified belief in the independent existence of mind and of body as (quasi-) substances. The modal aspect mental functioning as a mode of functioning that qualitatively differs from biological functioning - is substantialized and changed into a mental substance or a mental entity called 'The Mind'. Psychophysical identity theories, on the other hand, run the risk of being transformed into one or another form of monism. This occurs when the nature of the 'common ground' of different forms of functioning is defined in terms of one particular scientific discipline, such as biology (Glas, 2002:164).

Repko provides a penetrating analysis of various contemporary reductionist and antireductionist paradigms in the philosophy of mind. 24

23 "Und daß auf der anderen Seite ausgerechnet der Materiebegriff der schwierigste, unbewältigste und rätselhafteste Begriff überhaupt für die Wissenschaft dieses Jahrhunderts blieb" (Stegmüller, 1987:90).

24 He discusses the contributions of Dennett, Churchland, Searle and McGinn (see Repko, 2002). 


\section{Societal identities}

The philosophy of mind and social philosophy also struggled extensively with issues of personal identity (traditionally: the supposed relationship between body and soul and more recently, the just mentioned question regarding the identity of mind and brain) and with the complex relationships between the "individual" and "society" (collective identity). Am I in the first place someone with an ethnic identity (such as an Englishman, Zulu, Afrikaner or Sotho) and only in the second instance partaking in a specific political identity (such as being a South African, American, etcetera)?

The basic and important perspective in this context is that no single societal identity - however, much is considered to be a "social construction" - can escape both from fundamental ontic modes of explanation co-conditioning human society (such as the lingual, 25 the economic, the social, the aesthetic, the jural and the moral) and the various possible identities human beings can construe (and assume) in the process of, what Simmel calls, sociation. Simmel holds that a number of individuals are only transformed from a spatial aggregate or a temporal sequence into a society when (through sociation) these individuals exercise a mutual influence upon each other: "If, therefore, there is to be a science whose subject matter is society and nothing else, it must exclusively investigate these interactions, these kinds and forms of sociation" (see Levine, 1971:24-25). ${ }^{26}$

Therefore, one should also realise that the existence of no single human being is ever exhaustively encompassed by participating in

25 It should be noted that every mode of explanation has an universal scope in the sense that whatever there is in principle, has a function in every ontic mode of reality. Another way to refer to this state of affairs, is to speak about the modal universality of different aspects. This may provide an(other) interpretation of Derrida's statement that there is nothing outside the text different from his own eventual explanation. In terms of the modal universality of the sign mode, one can say that whatever there is within reality, will always also function within this aspect - suggesting that there is indeed nothing outside the "text", i.e., not functioning within the "text" or sign mode. Derrida eventually said that "[t]he phrase which for some has become a sort of slogan, in general so badly understood, of deconstruction ('there is nothing outside the text' [il n'y a pas de hors-texte]), means nothing else: there is nothing outside context" (Derrida, 1988:136). In terms of our suggestion: there is no entitary existence outside the context of (multiple) modal universality.

26 According to Simmel, however, the assumed reality of a supra-individual society is a fatal reification of a mere abstraction (cf. Ziegenfuss, 1956:14). 
any single social collectivity. 27 Consequently, the socially differentiated roles played by human beings within multiple societal collectivities, are always merely partial, entailing that any given person is always at once, i.e., simultaneously, participating in various social entities. 28

This means that at once a person may be a father, citizen, club member, and so on, participating in these distinct social identities, without fully being absorbed by any one of them. The mystery of the human being certainly coheres with the fact that no single differentiated social identity can fully and exhaustively encompass the nature of being human. 29

\section{Concluding remark}

The preceding discussion was mainly focused on the difference between an entity and the diverse modal aspects in which such an entity functions. The argument rests upon the assumption that an entity is transmodal in nature. The co-conditional role of functional aspects as modes of explanation, supported our argument that change can only be established on the basis of constancy. Yet, the step from constancy to an awareness of identity needed a further elaboration - given in our brief account of the difference between a conceptual and a concept-transcending use of modal terms.

\section{List of references}

ARISTOTLE. 2001. The basic works of Aristotle. Ed. by Richard McKeon. Introduction by C.D.C. Reeve. New York: The Modern Library. [This work contains Aristotle's Metaphysics referred to in the text.]

BRYON, D.A. \& SPIELBERG, N. 1987. Seven ideas that shook the universe. New York: Wiley.

CARNAP, R. 1967. The logical structure of the world: Pseudoproblems in philosophy. London: Routledge \& Kegan Paul.

DERRIDA, J. 1976. Of grammatology. Trans. by Gayatri Chakravorty Spivak. Baltimore: Johns Hopkins University Press.

27 Analogous to the nature of thermodynamically open physical systems (a fire, glacier, etcetera), various societal collectivities also continue their identity over time, in spite of the coming and going of individual members.

28 Of course specific conscious actions within specific social entities normally only take place in succession.

29 An analysis of the problem of individual and society is found in Strauss (2002 and 2004). 
DERRIDA, J. 1988. Limited inc. Evanston: Northwestern University Press.

DIELS, H., \& KRANZ, W. 1959/1960. Die Fragmente der Vorsokratiker. Band IIII. Berlin: Weidmannsche Verlagsbuchhandlung.

DOOYEWEERD, H. 1997. A new critique of theoretical thought, collected works of Herman Dooyeweerd. A-Series, Vols. I-IV. General ed. D.F.M. Strauss. Lewiston: The Edwin Mellen Press.

EINSTEIN, A. 1959. Autobiography. (In Schilpp, P.A., ed. Albert Einstein, philosopher-scientist. Vol. I. London: Harper \& Row.)

FINE, K. 2003. The non-identity of a meterial thing and its matter. Mind, 112:196-234.

FREEMAN, K. 1949. Companion the pre-Socratic philosophers. Oxford: Blackwell.

FREGE, G. 1987. Die Grundlagen der Arithmetik: Ein logisch mathematische Untersuchung über den Begriff Zahl. Stuttgart: Reclam.

FREGE, G. 2001. Schriften zur Logik und Sprachphilosophie: Aus dem Nachlaß. Hamburg: Felix Meiner.

FODOR, J.D. 1977. Semantics: Theories of meaning in generative grammar. Sussex: Harvard University Press.

GLAS, G. 2002. Churchland, Kandel and Dooyeweerd on the reducibility of mind states. Philosophia Reformata, 67(2)148-172.

HART, H. 1984. Understanding our world. Lanham: University Press of America.

JANICH, P. 1975. Trägheitsgesetz und Inertialsystem. (In. Thiel, C. Frege und die moderne Grundlagenforschung. Meisenheim am Glan: Hain. p. 66-76.)

JONES, A., ed. 1998 Science in faith: A Christian perspective on teaching science. Essex: Romford.

LEVINE, D.N. 1971. George Simmel, on individuality and social forms. Chicago: University of Chicago Press.

LOWE, E.J. 1998. The possibility of metaphysics, substance, identity and time. Oxford: Clarendon.

PLANCK, M. 1910 [1973]. Die Stellung der neueren Physik zur mechanischen Naturanschauung. (In Planck, M. Vorträge und Erinnerungen. Darmstadt: Wissenschaftliche Buchgesellschaft. p. 52-68.)

PLANCK, M. 1973. Vorträge und Erinnerungen. Darmstadt: Wissenschaftliche Buchgesellschaft.

PLATO. 1963. The collected dialogues of Plato: Including the letters. Ed. by Edith Hamilton \& Huntington Cairns. Princeton: Princeton University Press.

QUINE, W.V. 1958a. Mathematical logic. Cambridge: Harvard University Press.

QUINE, W.V. 1958b. Methods of logic. London: Routledge \& Kegan Paul.

QUINE, W.V. 1973. The roots of reference. Paul Carus Lectures. La Salle: Open Court Illinois.

REPKO, P. 2002. Philosophy of mind and the problem of consciousness: $A$ structural analysis of aspects of the reductionist and anti-reductionist paradigms. The views of Dennett, Churchland, Searle and McGin. Bloemfontein: University of the Free State. (M.A. thesis.)

SCHULTE, J. 1987. Nachwort. (In Frege, G. Die Grundlagen der Arithmetik: Ein logisch mathematische Untersuchung über den Begriff Zahl. Stuttgart: Reclam. p. 143-152.)

STEGMÜLLER, W. 1987. Hauptströmungen der Gegenwartsphilosophie. Vol. III. Stuttgart: Alfred Krüger Verlag. 
STRAUSS, D.F.M. 2000. Kant and modern physics: The synthetic a priori and the distinction between modal function and entity. South African Journal of Philosophy, 19(1):26-40.

STRAUSS, D.F.M. 2002a. Is it meaningful to juxtapose "individual" and "society"? Society in Trasition, 33(1):96-115.

STRAUSS, D.F.M. 2002b. The scope and limitations of Von Bertalanffy's systems theory. South African Journal of Philosophy, 21(4):291-305.

STRAUSS, D.F.M. 2003a. Frege's attack on "abstraction" and his defense of the "applicability" of arithmetic (as Part of Logic). South African Journal of Philosophy, 22(1):63-80.

STRAUSS, D.F.M. 2003b. How "rational" is "rationality"? South African Journal of Philosophy, 22(1):247-266.

STRAUSS, D.F.M. 2004. Transcending the impasse of individualism and universalism in sociological theory. Society in Transition, 35(1):165-182.

VAN INWAGEN, P. 2001. Ontology, identity, and modality; Essays in metaphysics. Cambridge: Cambridge University Press. (Cambridge Studies in Philosophy.)

VAN WOUDENBERG, R. 2000. Het mysterie van de identiteit, een analytischwijsgerige studie. Nijmegen: SUN.

VELING, K. 2000. Ruimte voor de rede, filosofie als systematische reflectie. Kampen: Agora.

VOLLENHOVEN, D.H. Th. 1967. Isagogè Philosophiae. Amsterdam: Philosophical Institute at the Free University.

VON BAADER, F. 1851. Sämtliche Werke. Gesammelte Schriften zur philosophischen Erkenntniswissenschaft als spekulative Logik. Beiträge zur dynamischen Philosophie im Genesatze der mechanischen. Aalen: Scientia.

VON KIBÈD, A.V. 1979. Einführung in die Erkenntnislehre, die Grundrichtungen und die Grenzen der Erkenntnis der Wahrheit. München: Reinhardt.

ZIEGENFUSS, W 1956. Handbuch der Soziologie. Stuttgart: Enke.

\title{
Key concepts:
}

\author{
change \\ concept-transcending knowledge \\ conceptual knowledge \\ identity
}

\section{Kernbegrippe:}

begrip-transenderende kennis

begripskennis

identiteit

verandering 